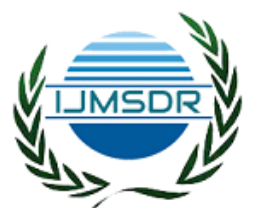

\title{
Educational Affect About Triage Against Nurses Ability In Implementing Triage In Emergency Room Palembang Hospital
}

\author{
Mutmainah Handayani ${ }^{1}$, Alkhusari ${ }^{2}$, Muhamad Andika Sasmita Saputra ${ }^{3}$ \\ ${ }^{1}$ Nursing Science, Kader Bangsa University, Palembang) \\ ${ }^{21}$ Nursing Science, Kader Bangsa University, Palembang) \\ ${ }^{31}$ Nursing Science, Kader Bangsa University, Palembang)
}

\begin{abstract}
Based on data obtained from the emergency room at Palembang Hospital, the number of emergency room visits in 2019 was 7,444 visits. This research was conducted in February - March 2020. The population of this study was nurses in the Emergency Room at the Hospital in Palembang.This study used an experimental method with a quasi-experimental research technique with a Pre-Post Test Design research design. Results of research on the Effects of Education on Triage Against Knowledge in the Implementation of Triage in the Emergency Room of the Hospital of Palembang Hospital, the results of the t test statistic test the average value of the pre test was 60.19 with a percentage of $62.5 \%$, had a good level of knowledge, 25, $0 \%$ have a sufficient level of knowledge, $12.5 \%$ have less knowledge. The average value of the post test was 66.75 with a percentage of $81.25 \%$ having a good level of knowledge, $12.5 \%$ having a sufficient level of knowledge, $6.25 \%$ having a low level of knowledge. Palembang Hospital is expected to continue to improve nurses' knowledge through various training and seminars on triage.
\end{abstract}

Keywords : Pengetahuan, Perawat, Triage.

\section{INTRODUCTION}

Triage comes from the French language "Tier" which means to divide into three groups (Department of Emergency Medicine Singapore General Hospital (DEM SGH), 2005). This system was developed in the battlefield and used when disaster strikes. Triage is also applied in the scope of a disaster or mass disaster. The aim of triage in mass accidents is that with minimal resources can save as many victims as possible. In a mass disaster with tens or perhaps hundreds of victims where a good number, ability, facility, and infrastructure helper is inadequate, it is recommended to use the simple Triage and Rapid Treatment technique. prevent late handling in emergency cases. Therefore it requires good knowledge and skills so that the handling of the case becomes fast and precise so that research needs to be carried out on "The Effect of Education About Triage Against Nurses' Knowledge in the Implementation of Triage Emergency Room Hospital Palembang"

\section{Case report}

In this study the normality test was conducted first to find out whether the data was normally distributed or not by the Shapiro-Wilk analytical method because of a sample of $\leq 50$ people. Normality test is said to be normal if the p-value $\geq 0.05$. After knowing the data distribution is normal or not, then the paired group test is performed. 
Table 4.1

Normality Test Before and After counseling

\begin{tabular}{|l|r|r|r|r|r|r|}
\hline \multirow{2}{*}{} & \multicolumn{3}{|c|}{ Kolmogrov-Smirnov $^{\mathrm{a}}$} & \multicolumn{3}{c|}{ Shapiro-Wilk } \\
\cline { 2 - 7 } & Statistic & \multicolumn{1}{c|}{ df } & \multicolumn{1}{c|}{ Sig. } & Statistic & \multicolumn{1}{c|}{ Sig } \\
\hline Before & .137 & 16 & .200 & .937 & 16 & .316 \\
\hline After & .161 & 16 & .200 & .954 & 16 & .561 \\
\hline
\end{tabular}

Table 4.2

Frequency Distribution of Nurses' Knowledge of Triage in the Implementation of Triage at the before test in the Emergency Room at Palembang Hospital

\begin{tabular}{|c|l|c|c|}
\hline No & Knowledge & Amount & Percentage (\%) \\
\hline 1 & Good $76 \%-100 \%$ & 10 & $62,5 \%$ \\
\hline 2 & Enough 56\% - 75\% & 4 & $25,0 \%$ \\
\hline 3 & Less $>56 \%$ & 2 & $12,5 \%$ \\
\hline \multicolumn{2}{|c|}{ Jumlah } & 16 & $100 \%$ \\
\hline
\end{tabular}

Table 4.3

Frequency Distribution of Nurses' Knowledge About Triage in the Implementation of Triage at the after test in the Emergency Room at Palembang Hospital

\begin{tabular}{|c|l|c|c|}
\hline No & Knowledge & Amount & Percentage (\%) \\
\hline 1 & Good $76 \%-100 \%$ & 13 & $81,25 \%$ \\
\hline 2 & Enough $56 \%-75 \%$ & 2 & $12,5 \%$ \\
\hline 3 & Less $>56 \%$ & 1 & $6,25 \%$ \\
\hline Amount & 16 & $100 \%$ \\
\hline
\end{tabular}

Tabel.4.4

Differences in the level of knowledge of nurses in implementing triage before and after being given education about triage in the emergency room at Palembang Hospital

\begin{tabular}{|c|c|c|c|c|c|c|c|c|c|c|}
\hline \multirow{2}{*}{ Knowledge } & \multicolumn{2}{|c|}{ Good } & \multicolumn{2}{|c|}{ Enough } & \multicolumn{2}{|c|}{ Less } & Amount & Persentage & \multirow{2}{*}{ Mean } & \multirow{2}{*}{ Sig } \\
\cline { 2 - 11 } & $\mathrm{N}$ & $\%$ & $\mathrm{~N}$ & $\%$ & $\mathrm{~N}$ & $\%$ & $(\mathrm{n})$ & $\%$ & & \\
\hline Before test & 10 & 62,5 & 4 & 25,0 & 2 & 12,5 & 16 & 100 & 60.19 & .000 \\
\hline After test & 13 & 81,25 & 2 & 12,5 & 1 & 6,25 & 16 & 100 & 66.75 & \\
\hline
\end{tabular}

\section{DISCUSSION}

Based on the results of normality (Shapiro-wilk) it can be seen that the p-value> 0.05 is in the pre-test of 0.316 , in the After-test of 0.561, so it is concluded that the data distribution in the experimental group is normal and can use the $\mathrm{t}$-dependent test. The results of the level of knowledge of nurses before being given education about triage in the emergency room of Palembang Hospital, it is known that those who have good knowledge are 10 nurses with a percentage of $62.5 \%$, enough as many as 4 nurses with a percentage of $25.0 \%$, and less as many as 
2 nurses with a percentage of $12.5 \%$. The results of the level of knowledge of nurses after being given education about triage in the emergency room of Palembang Hospital, it is known that there are 13 nurses with good knowledge with a percentage of $81.25 \%$, less as many as 2 nurses with a percentage of $12.5 \%$, and less as 1 nurse with a percentage of $6.25 \%$.

The bivariate analysis aims to see differences in nurses' knowledge in the implementation of triage before and after being given education about triage in the emergency room at Palembang Hospital. The results of the t test statistic test can be seen that the average value of the befpre test is 60.19 with a percentage of $62.5 \%$, has a good level of knowledge, $25.0 \%$ has a sufficient level of knowledge, $12.5 \%$ has a level of less knowledge. The average value of the after test was 66.75 with a percentage of $81.25 \%$ having a good level of knowledge, $12.5 \%$ having a sufficient level of knowledge, $6.25 \%$ having a low level of knowledge. From the table above it can be seen that there is an influence of education on the level of knowledge of nurses before and after knowledge is given. This difference was tested with paired t yielding a $\mathrm{p}$-value $=0.000$, obtained from the 2-tail sig column The statistical test results obtained $p$-value $=0.000$, where the value is greater than the value of $\alpha=0.05$, so it can be concluded that there are significant differences between pre-test and post-test, then it can be concluded that there is a significant difference between before giving education about triage with after being given education about triage so that Ho is rejected and $\mathrm{Ha}$ is accepted.

\section{CONCLUSION}

Nurses' knowledge about triage before being given education is 60.19 with a percentage of $62.5 \%$, having a good level of knowledge, $25.0 \%$ having a sufficient level of knowledge, $12.5 \%$ having a low level of knowledge. The average level of knowledge of nurses after being educated about triage, after being given triage education is equal to 66.75 with a percentage of $81.25 \%$ having a good level of knowledge, $12.5 \%$ having a sufficient level of knowledge, $6.25 \%$ having a low level of knowledge.

There is a difference in the influence of the level of knowledge about triage in the emergency room of the Palembang Hospital before and after being given education about triage with an average difference of 6,562 and p-value $=0,000$

\section{REFERENCES}

[1.] Balmford, A. et al. (2000) Integrating costs of conservation intointernational priority setting. Conserv. Biol. 14, 597-605. [PubMed] [Google Scholar].

[2.] Repine, T.B. et al. (2005) The dynamics and ethics of triage: rationingcare in hard times. Mil. Med. 170, $505-509$

[3.] Richardson D. No relationship between emergency departmentactivity and triage categorization. AcadEmerg Med.1998; 6:141-5.

[4.] National Center for Injury Prevention and Control. DataElements for Emergency Department Systems, Release 1.0. Atlanta,GA: Centers for Disease Control, 1997.

[5.] Lowe RA, Bindman AB, Ulrich SK, et al. Refusing care toemergency department patients: evaluation of published triageguidelines. Ann Emerg Med 1994; 23:286-93.SAEM Ethics Committee. Ethics of emergency departmenttriage. AcadEmerg Med. 1995; 2:990-5.

[6.] Sundes K, Birnbaum M. Health disaster management guidelinesfor evaluation and research in the Utstein style. PrehospitalDisaster Med 2003;17(Suppl. 3):33. 
[7.] Hammad K, Arbon P, Gebbie K. Emergency nurses and disasterresponse: an exploration of South Australian emergency nurses'knowledge and perceptions of their roles in disaster response.AustralasEmergNurs J 2011;14:87-94.

[8.] Arbon P, Cusack L, Hammad K, Woodman R, Kako M, BahnischL, Ranse J, Shaban R, Considine J, Mitchell B. Understandingthe willingness of emergency nurses to respond to a disaster. Research Report Flinders University; 2011.

[9.] Duong K. Disaster education and training of emergency nursesin South Australia. AustralasEmergNurs J 2009;12:86-92. 